\title{
EMIGRANT O EMIGRANTACH. OSKARA MIEOSZA I JOSIFA BRODSKIEGO PORTRETY BEZ SKAZY
}

\author{
AGNIESZKA CZYŻAK1 \\ (Poznań)
}

\begin{abstract}
Słowa kluczowe: Oskar Miłosz, Josif Brodski, emigracja, poezja, hierachia
Keywords: Oskar Miłosz, Josif Brodski, Eastern Europe, emigration, poetry, hierarchy
\end{abstract}

\begin{abstract}
Abstrakt: Agnieszka Czyżak, EMIGRANT O EMIGRANTACH. OSKARA MIŁOSZA I JOSIFA BRODSKIEGO PORTRETY BEZ SKAZY. „PORÓWNANIA” 10, 2012, Vol. X, s. 109-122. ISSN 1733-165X. Punktem wyjścia artykułu, analizującego związki pomiędzy tworzonymi przez Czesława Miłosza literackimi portretami innych poetów - Oskara Miłosza i Josifa Bodskiego - a jego licznymi autoportretami jest doświadczenie życia na emigracji, traktowane jako szczególne wyzwanie egzystencjalne. Życiorys Miłosza, kreowany przez niego na wygnaniu jako „biografia wieszcza" a równocześnie „biografia poety światowego” wymagał stworzenia kontekstu biografii podobnych: poetów-emigrantów z Europy Wschodniej odnoszących sukces literacki poza krajem rodzinnym. Jednak najważniejszą więzią między tymi poetami okazała się - w twórczości Miłosza - „hierarchiczność” pojmowana jako opór przeciw wszelkiemu relatywizmowi oraz niezłomna wiara w konieczność rozróżniania tego, co wysokie, od tego, co niskie.
\end{abstract}

\begin{abstract}
Agnieszka Czyżak, EMIGRANT ABOUT EMIGRANTS. OSKAR MIŁOSZ AND JOSIF BRODSKI'S FLAWLESS PORTRAITS. "PORÓWNANIA" 10, 2012, Vol. X, p. 109-122. ISSN 1733165X. This article is an analysis of associations between the portraits of other poets created by Czesław Miłosz, namely Oskar Miłosz and Josif Brodzki, and his self-portraits. The starting point is the experience of emigrant life treated as an unusual existential challenge. Miłosz's biography, created by him in exile as a "biography of a great national poet" and simultaneously "the biography of a world poet" demands context of similar life-histories: emigrant poets from Eastern Europe successfully forming their literary careers out of homeland. However, the most important connection between those poets is - in Miłosz's writing - "the hierarchy", interpreted as a resistance against relativism and as an inflexible belief about the necessity of differentiation between that which is high and that which is low.
\end{abstract}

${ }^{1}$ E-mail Address: agaczyz@amu.edu.pl 
W roku 1985 ukazał się zbiór rozpraw naukowych i tekstów krytycznych zatytułowany Poznawanie Miłosza. Tom, którego pomysłodawcą i redaktorem był Jerzy Kwiatkowski, i wtedy, i dziś sprawia wrażenie „pospolitego ruszenia”, którego uczestnicy, znamienici badacze, postanowili przyswoić fenomen pisarstwa poetyemigranta, nieznanego w owym czasie szerszej publiczności. Wytłumaczyć zaskoczonym światowym sukcesem twórczości Miłosza odbiorcom, na czym polega jej wielkość.

Potrzebą tamtego czasu było tak naprawdę „oswajanie” Miłosza, niwelowanie różnic, włączanie całości jego dzieła w istniejące porządki, podkreślanie podobieństw i osadzanie $\mathrm{w}$ tradycyjnych kontekstach. Emigracyjny twórca, będący wówczas postacią na poły mityczną, egzystującą w oddaleniu, za nieprzekraczalną barierą politycznych granic, zdawał się budzić powszechnie pozytywne reakcje od uwielbienia po częściową choćby aprobatę. Jednak wiele z powstałych wówczas krytycznych rozpoznań wskazywało późniejsze kierunki recepcji twórczości Miłosza. Jan Błoński tak wyjaśniał specyfikę jego liryki:

Czym więc są momenty olśnień i objawień? Niczym innym jak - dostępnymi każdemu - chwilami doznań zmysłowych tak intensywnych, że prowadzą do roztopienia się podmiotu w przedmiocie [...] Poezja jest może sekretem, ale nie mówi o niczym, co tajemne; cieszy się i syci światem codziennego doświadczenia²

Błoński na długo przed powstaniem tomów składających się ostatecznie na późną twórczość poety diagnozował:

Liryczny egotyzm (który bynajmniej nie znika, i chwała Bogu, bo poezja potrzebuje osobności i wyniosłości) staje się częścią stylistyki wspólnoty. Tak pieśń zmienia się w symfonię. Późna twórczość Miłosza jest ogromnym przedsięwzięciem uspołecznienia i sakralizacji osobistego doświadczenia. „Ocalanie”, o którym mówił tak często, nie jest tylko ocalaniem siebie i dla siebie, staje się ocalaniem innych i dla innych ${ }^{3}$.

Badacz wskazał więc, iż emigracyjna poezja Miłosza bywała najczęściej rozpięta między zapisem jednostkowych epifanii, a świadomie podjętym trudem ocalania wartości dla wspólnoty. Takie działania przeprowadzane w oddaleniu od codzienności zbiorowego życia mogły być wpisywane $\mathrm{w}$ utrwalony $\mathrm{w}$ kulturze wzorzec tworzenia przesłań do narodu przez emigracyjnego wieszcza. Jednak celowa strategia twórcy dążącego - na pewnej płaszczyźnie - do wykształcenia wyrazistej poetyckiej dykcji: nacechowanego aksjologicznie i skierowanego ku zbiorowości wykorzystywania własnych, jednostkowych, lirycznych olśnień w zmienionych po przełomie 1989 roku warunkach, okazała się strategią przyno-

2 J. Błoński, Epifanie Miłosza, w: J. Kwiatkowski (red.), Poznawanie Miłosza. Studia i szkice o twórczości poety. Kraków 1985, s. 210.

${ }^{3}$ Ibidem, s. 223. 
szącą skutki ambiwalentne. Niezmiennym, a nawet rosnącym odczuciom akceptacji i uznania zaczęły towarzyszyć równie silne emocje negatywne: niechęć, niezrozumienie, odmowa praw - traktowanych teraz jak uzurpacja - do jakiejkolwiek formy nauczania, uznawanego za zbędne moralizatorstwo lub pozbawione wspólnotowej legitymizacji narzucanie jednostkowych przekonań.

Tymczasem dydaktycznie nacechowane były również wybory translatorskie, popularyzatorskie czy analityczne Miłosza. Skład antologii poetyckich oraz wybór tematów tekstów eseistycznych i krytycznych podporządkowane zostały świadomie podjętemu zadaniu nauczania wspólnoty - niezależnie od tego, czy adresatem konkretnych utworów była wspólnota narodowa, europejska czy ogólnoludzka. Ten wyrazisty rys twórczości poety, szczególnie rozpoznawalny w ostatnim ćwierćwieczu jego życia bywał postrzegany jako podjęcie narzuconego sobie "prywatnego obowiązku”, choćby jego realny wpływ, nawet na kształt życia literackiego własnego kraju, okazywał się złudzeniem. Z pasją, z jaką niektórzy oddają się działalności charytatywnej, poeta oddawał się misji nauczania, wyjaśniania, interpretowania. Agata Stankowska badając spójność liryki Miłosza z jego manifestami - z reguły kierowanymi przeciw rozmaicie definiowanej „poezji niezrozumiałej" - stwierdziła, iż poeta:

nigdy nie ukrywał, że chce wpływać na rozwój liryki polskiej, recenzować i projektować jej teraźniejszy i przyszły kształt [...] Wzywał i postulował. Gromadził i siał ziarno - w jego mniemaniu dla "gospodarstwa polskiej poezji” najzdrowsze. [...] Autor słów o lawinie, która zmienia bieg zależnie od kamieni, po jakich się toczy, wierzył, że choćby pojedyncze, ale świadome działania mogą wpłynąć na zmianę najsilniejszych nawet koniunktur i, zdawałoby się, nieusuwalnych żywiołów współczesnego poezjowania4.

Podobny, wyrastający z osobistego zobowiązania wobec wspólnoty i również nacechowany dydaktycznie charakter miały tworzone przez Miłosza w ciągu całego życia niezliczone autoportrety oraz tworzące ich kontekstualne tło portrety twórców z różnych epok i różnych nacji. Tekst Nasza wspólnota z tomu Piesek przydrożny stanowi zapis pozbawionej złudzeń diagnozy:

Zawiści artystów. Mimo komizmu, nie jest to wesołe widowisko. Każdy utopiłby drugiego w łyżce wody. Przyglądając się temu przez lata ma się czarne myśli [...] sława poematu albo płótna pokrytego farbą jest najzupełniej abstrakcyjna, jako że człowiek umrze i na nic mu nie będzie potrzebna ta sława. Jednakże gra nie toczy się o przyszłość, ale o wyobrażenie o sobie ${ }^{5}$.

Miłosza $\mathrm{z}$ wieloma pisarzami łączyły $\mathrm{w}$ ciągu długich lat życia burzliwe związki, o zmiennym natężeniu emocjonalnym, a także rozmaicie postrzegane

${ }^{4}$ A. Stankowska, Głos Mitosza w sprawie o "niezrozumialstwo" jako ponowiony wybór tradycji. „Pamiętnik Literacki", CII, 2011, z. 2.

${ }^{5}$ Cz. Miłosz, Piesek przydrożny. Kraków 1997, s. 74. 
oraz interpretowane przez niego na różnych etapach biografii. Tym bardziej interesujące wydaje się sfunkcjonalizowanie portretów zarysowanych od początku wyrazistą kreską, nie podlegających retuszom. Jak się zdaje służyć miały przede wszystkim wspomaganiu tekstowych realizacji owego "wyobrażenia o sobie”, a nawet stanowić ich integralną część. Istniały obok interpretacji dzieł stanowiących namysł nad ich przesłaniem połączony z nastawieniem polemicznym. Z reguły $\mathrm{w}$ tej funkcji występowały ponawiane wielokrotnie wizerunki starszego o trzy dekady, późno poznanego i przedwcześnie utraconego krewnego, Oskara Miłosza, oraz młodszego o trzy dekady Josifa Brodskiego, którego dane mu było przeżyć o kilka lat. Miłosz zresztą był świadomy swojej skłonności do nauczania poprzez tworzenie literackich wizerunków. W Piesku przydrożnym pojawia się diagnoza i deklaracja:

olbrzymia ilość twarzy, postaci i losów poszczególnych istnień i rodzaj utożsamiania się z nimi od ich wnętrza, a zarazem świadomość, że nie znajdę już sposobu, żeby tym moim gościom ofiarować dom w moich wierszach, bo już za późno. Myślę też, że gdybym zaczynał na nowo każdy mój wiersz byłby życiorysem albo portretem jakiejś konkretnej osoby, a ściślej, lamentem nad jej przeznaczeniem ${ }^{6}$.

Deklarację tę można dziś odczytywać jako sugestię właściwego - bo pełnego empatii i „uważności” - interpretowania portretów i życiorysów wszystkich skazańców wrzuconych w ziemskie bytowanie, zmagających się z wyrokami Historii, pułapkami losu, udrękami codzienności. Deklarowana litość wobec portretowanych może oznaczać nie tylko zdolność obdarzania współczuciem członków ludzkiej wspólnoty, ale i późno zdobytą umiejętność wybaczania sobie. Poprzez tworzenie portretów pozytywnych, swoiście paralelnych, Miłosz wspomagał niekończący się akt kreowania własnego wizerunku, a ich zastygły w jednym kształcie tekstowy byt uruchamiany bywał w funkcji poręcznego argumentu. Sposób interpretowania przebiegu życia „emigrantów ze Wschodu” zdaje się jedną z dyrektyw czytania jego własnych dziejów, a zarazem wizją swoistej, pokoleniowej „zmiany warty" w służbie poezji wysokiej.

Marek Zaleski, badając życiorys Miłosza jako „arcywzór biografii poety”, będący zarazem swoistą grą z biografią Mickiewicza, wskazał na jego cechy konstytutywne:

Buntował się przeciw wspólnocie Lechitów, i ofiarowywał się wspólnocie, bo czymże innym, aniżeli rodzajem takiego składania siebie $\mathrm{w}$ ofierze była gorliwość, $\mathrm{z}$ jaką uprawiał sztukę autokomentarza. Ten przymus nieustannych autoprezentacji zastanawia: bierze się z poczucia zobowiązania tyleż wobec siebie, co trybunału wspólnoty. Była w tym pasja samowiedzy - zgoda! Ale był też dyktowany potrzebą zadość-

${ }^{6}$ Ibidem, s. 163. 
uczynienia owemu społecznemu zamówieniu silny wymóg reżyserowania swego konterfektu ${ }^{7}$.

Trudne, a nigdy jednoznaczne związki Miłosza ze „wspólnotą Lechitów” spełniać się mogły właśnie $\mathrm{w}$ podejmowanym nieustannie trudzie nauczania - tekst biografii stanowił centralny projekt tak pojmowanej misji.

Reżyserowaniu siebie towarzyszyło niemal od początku, postrzegane nieraz jako natrętne, a zawsze bezdyskusyjnie jednoznaczne portretowanie Oskara Miłosza, jako twórcy, którego dzieło jest równe rangą paralelnie dokonanym odkryciom Einsteina. Pełne niekłamanego zachwytu i szacunku prezentowanie dzieła kuzyna miało charakter świadomie tworzonego wzorca osobowego. Status emigranta wymagał podjęcia wysiłku stałego rekonstruowania tożsamości. Mieszkaniec Wschodu zmuszony określać siebie wobec realiów zachodniego świata odnajdywał w życiorysie "francuskiego poety z Litwy" wzór samostanowienia i realnej duchowej autonomii.

Nie wszystkie, co prawda, decyzje Oskara Miłosza pozostały wypełnionym wskazaniem dalszej drogi twórczej pisarza, już w młodości zafascynowanego duchową niepodległością i twórczą niezależnością starszego krewniaka. Andrzej Franaszek stwierdził:

Postawa Oskara Miłosza, rezygnującego z walki o literackie laury, miała w sobie żarliwość proroka czy ewangelicznego ucznia, porzucającego wszystko, by iść za głosem Boga. Autor Trzech zim, który w sztuce osiągnął nieporównanie więcej, nigdy nie zdobył się na tę krańcowość8.

Jednak innego rodzaju krańcowość - znajdowania osobnych, nie wyznaczanych przez obowiązujące mody czy „nakazy epoki” dróg zarówno artystycznego rozwoju, jaki i modelowania tożsamości stała się rzeczywistym natchnieniem. Ważniejsza okazała się zatem umiejętność łączenia bolesnych rozpoznań kondycji świata naznaczonego rozpadem $\mathrm{z}$ pozornie niemożliwym do pogodzenia natchnieniem nadzieją jego przyszłej odnowy. Nade wszystko zaś istotnym wzorcem pozostała anachroniczna, lecz autentyczna żarliwość w dawaniu świadectwa: „Wiara Oskara Miłosza w przyszłe odrodzenie ludzkości, a także w boską jedność czasu, ducha i materii, będzie jednym ze źródeł nadziei, ukrytej na dnie wierszy jego ucznia, nadziei niepozwalającej oddać się rozpaczy" ${ }^{\prime \prime}$.

Kilkadziesiąt lat po śmierci kuzyna, tworząc jego apologetyczny portret w Ziemi Ulro, a zarazem kreując na jednego z najważniejszych duchowych przewodników, Miłosz przyzna:

${ }^{7}$ M. Zaleski, Arcywzór biografii poety, w: H. Gosk, A.S. Kowalczyk (red.), Pisarz na emigracji. Mitologie, style, strategie przetrwania. Warszawa 2005, s. 410.

8 A. Franaszek, Czestaw Miłosz. Biografia. Kraków 2011, s. 219.

9 Ibidem, s. 225. 
Tożsamość nazwiska i moje pragnienie ojcowskiego autorytetu nie wystarczyłyby, żeby pismom O. W. M. zapewnić aż taki wpływ, jaki na mnie wywarły. Nic bym w nich nie znajdował, gdyby nie to, że zaznałem nieszczęść, prywatnych i publicznych, i że przez całe prawie życie funkcjonowałem z trudem, na samej granicy krzyku [...] O.W. M. był poetą miłości, ale nie słodka to była miłość, przeciwnie, jakby drugiego stopnia, drogo opłacona. I dzieło jego, a zwłaszcza jego poezja metafizyczna, boryka się ze starym pytaniem: jak można naszemu istnieniu na ziemi powiedzieć: „'tak”10.

Miłosza oprócz skrajnego indywidualizmu i manifestowanej osobności oraz niezbywalnego nakazu niepodlegania modom (nie tylko literackim) pociągała w dziele krewnego zdolność tworzenia wizji trudnej, okupionej wysiłkiem zgody na bytowanie $\mathrm{w}$ zastanej rzeczywistości. Podobieństwo sytuacji egzystencjalnej, nade wszystko konieczność odnajdywania własnego miejsca w obcym świecie, w warunkach emigracji zmuszały obu twórców i do wykorzystywania, i poddawania świadomie prowadzonej grze tradycyjnych rozpoznań, uzależniających byt emigranta od losów porzuconej zbiorowości, przy jednoczesnym poszukiwaniu sposobów ich ostatecznego przekroczenia.

Miłosz, który uważał, iż „opór wobec poezji innego języka należy uznać za zaletę" a zarazem jedną z konstytutywnych cech kształtowania własnej twórczej odrębności, podobną wagę przykładał do manifestowania poczucia przynależności do miejsca narodzin. U kresu życia podkreślał z pełnym przekonaniem: „Rodzimy się w określonym punkcie kuli ziemskiej i temu punktowi musimy dochować wierności, zachowując miarę w naszym dostosowaniu do mód cudzoziemskich"11. Jednak patriotyzm musiał być odczuciem o indywidualnie zakreślanych granicach, wierność nie tyle wobec narodu, co wobec jego kultury oparta na jednostkowo kształtowanych zasadach, a przywiązanie do miejsca urodzenia nie oznaczające przymusu zamknięcia w jego ciasnej przestrzeni oraz wzrastającej na jego podłożu nostalgii - tylko tak zmodyfikowane emocje mogły pozwolić czynnie kształtować emigracyjną tożsamość.

Oskar Miłosz, naturalizowany Francuz, który podkreślał, że jest Litwinem autor adaptacji litewskich podań i ludowych pieśni - decyzję o własnej przynależności narodowej traktował jak niezbywalne prawo każdej jednostki. Jego krewny postrzegał to jako wzór stawiania oporu wobec przeznaczenia, wzór duchowej autonomii:

Prawda jest taka, że Litwinem, tak jak Francuzem, także był z wyboru. Jego losem było wędrowanie i trwające przez całe życie poszukiwanie miejsca, w sensie zarówno ziemskim, jak i metafizycznym. Jako arystokrata - a wierzył w pamięć przodków zachowaną we krwi - chciał pozostać wierny swojej podwójnej, szlacheckiej i żydowskiej genealogii. $\mathrm{W}$ tym względzie także wszedł w spór $\mathrm{z}$ obowiązującą $\mathrm{w}$ jego czasach normą ${ }^{12}$.

\footnotetext{
${ }^{10}$ Cz. Miłosz, Ziemia Ulro. Warszawa 1982, s. 220.

${ }^{11}$ Cz. Miłosz, Spiżarnia literacka. Kraków 2004, s. 88.

${ }^{12}$ Cz. Miłosz, Oskar Miłosz, w: Historie ludzkie, "Zeszyty Literackie” 2007, nr 5, s. 77.
} 
W strategii służącej odnalezieniu osobnego, zaakceptowanego jako własny, modelu egzystencji poza granicami wyznaczanymi przez etniczną przynależność rozpoznać można zasadę twórczego wykorzystywania elementów zestereotypizowanego modelu emigranckiego losu $\mathrm{z}$ wykraczającymi poza ten model dyrektywami konstruowaniu biografii osobnej - poszukiwania „formy bardziej pojemnej" również w długotrwałym procesie uporczywego dążenia do stworzenia przejrzystego obrazu własnej tożsamości. Miłosz już w Rodzinnej Europie twierdził z przekonaniem: „Wszelkie fałsze wschodnich Europejczyków do „centrów kultury « pochodzą z nieśmiałości: naśladują zamiast się przeciwstawiać, są odblaskiem zamiast być sobą"13.

Poszukiwanie własnego miejsca poza krajem rodzinnym to zatem poszukiwanie przestrzeni niejako eksterytorialnej - niezależnie od tego, czy będzie to ambasada, czy uniwersytet - przestrzeni, w której można będzie, kultywując czułą pamięć o pierwszej ojczyźnie, konstruować tożsamość wędrowca, Odysa, któremu nie dane będzie wrócić do rodzinnych stron lub Eneasza, którego każdy nowy dom będzie schronieniem jedynie tymczasowym. Obroną przed rozpaczą może stać się zmiana statusu wygnańca czy pielgrzyma na świadomie podjętą rolę misjonarza, którego sensem egzystencji będzie nauczanie, dawanie świadectwa, tłumaczenie, a nade wszystko budowanie hierarchicznych porządków.

Nie tylko u Miłosza i Brodskiego spotkać można - choć rzadziej na początku ich emigracyjnej drogi - pełne czułości wspomnienia o miejscu urodzenia: Itace, którą trzeba koniecznie opuścić, by wkroczyć na trudną drogę ku samopoznaniu. Podobnym tonem przesycony jest wiersz Oskara Miłosza Bezsenność:

Bo młoda Miłość, która znała takie śliczne baśnie

Ukryła się tam, a wspomnienie czeka już oto trzydzieści lat

I nikt stamtąd nie woła: Miłość śpi.

O domu, domu! Czemu dałeś mi odjechać,

Czemu nie chciałeś mnie zachować, czemu Matko,

Pozwoliłaś kiedyś, żeby kłamliwy wiatr jesienny

I ogień na kominku, w długie wieczory, żeby ci czarodzieje

Ty, która znałaś moje serce, tak mnie kusili

Szalonymi gawędami w których pełno staroświeckich wysp ${ }^{14}$

Opuszczenie Itaki, obok pielęgnowania jej idealizowanego wizerunku, wymaga jednak przede wszystkim podjęcia wysiłków skutecznego oswojenia przestrzeni nowych doświadczeń

${ }^{13}$ Cz. Miłosz, Rodzinna Europa. Kraków 2001, s. 209. Nie trzeba dodawać, iż w tym względzie nauczycielem był Oskar Miłosz. W dalszej części wywodu czytamy: „On przez samo swoje istnienie przeprowadzał na mnie kurację i dzięki niej umacniała się we mnie pogarda awangardowych kapliczek tam, skąd przychodziłem, łowiących uchem nowości z Paryża".

${ }^{14}$ Cz. Miłosz, Historie ludzkie..., op. cit., s. 38-39. 
Życie na emigracji w realiach drugiej połowy XX wieku, po cywilizacyjnej katastrofie, w obliczu przemian kulturowych osiągających wymiar globalny, wymagało nieustannego zmagania się nie tylko $\mathrm{z}$ własnym osamotnieniem, ale $\mathrm{z}$ odczuciami powszechnego wykorzenienia $\mathrm{z}$ egzystencji i totalnej, wszechogarniającej bezdomności w naznaczonym obcością świecie. Wędrowanie, błądzenie, poszukiwanie - w przypadku Miłosza połączone z poczuciem winy i wyrzutami sumienia wywołanymi przez okoliczności pozostania na emigracji - to egzystencja w stanie zawieszenia pomiędzy oczywistym pragnieniem jakiejkolwiek stabilizacji a wiarą w poznawczy sens stawania wobec niekończących się wyzwań, będących codziennością „,człowieka w ruchu”. Iwaszkiewicz, jako szczególnie nieżyczliwy recenzent Rodzinnej Europy, zapisał w dzienniku pod datą 21 października 1960 roku:

A u niego to męczące gromadzenie dowodów, że on się nie nadawał do życia w Polsce. Ależ nie nadawał się i do życia w Ameryce, do życia w ogóle. Przecież on jest albatrosem. [...] Dziwny jest los tego człowieka, wieczny niepokój samouwielbienia. Ale i coś z naiwnej, wschodniej wiary w możność uzyskania odpowiedzi „na wszystkie pytania"15.

Miał rację Aleksander Fiut, pisząc o Miłosza „wrastaniu w Amerykę"16 (przeciwstawiał zresztą $\mathrm{w}$ swoim artykule jego wybory $\mathrm{z}$ "obierającymi inną strategię wrastania" Jerzym Kosińskim i Andrzejem Brychtem), iż było to raczej symboliczne oswajanie przestrzeni, w której można pogodzić się ze statusem wygnańca, a nawet dotrzeć do gorzkiego przekonania, że wygnanie jest przeznaczeniem każdego człowieka. Z kolei Bożena Karwowska, badając związki literackich ekspresji samoświadomości wygnańczej Miłosza i Brodskiego z przemianami kulturowymi i narodzinami dyskursu postkolonialnego, wskazała na konsekwencje obranej drogi, na fakt, iż już w latach osiemdziesiątych:

zarówno Miłosz jak i Brodski (z podobnych zresztą powodów, gdyż obaj nie ograniczali się do „wąskich horyzontów archipelagu wygnania") nie dawali się sklasyfikować w ramach emigracyjnych grup swoich rodaków, zaczęto widzieć ich jako członków międzynarodowej plejady, którą krytyka określiła mianem „poetów na wygnaniu” lub „pisarzy bez nacji"17.

15 J. Iwaszkiewicz, Dzienniki 1956-1963. Warszawa 2010, s. 422.

${ }^{16}$ A. Fiut, Wrastanie w Amerykę. (Strategie pisarskie: Czesława Miłosza, Jerzego Kosińskiego i Andrzeja Brychta), w: Pisarz na emigracji..., op. cit., s. 255. Badacz pisze: „właśnie w Nowym Świecie nastąpiło $\mathrm{w}$ jego doświadczeniu wewnętrznym, dość nieoczekiwanie i paradoksalnie, pogodzenie statusu wygnańca z kraju rodzinnego, uchodźcy czy obcego z wrodzoną każdemu potrzebą umiejscowienia. A zatem takiego uporządkowania przestrzeni otaczającej jednostkę, by w nowym otoczeniu odnalazła swój dom tyleż rzeczywisty, co symboliczny".

17 B. Karwowska, Kategoria wygnania w anglojezycznych dyskursach krytycznoliterackich (Czestaw Mitosz, Josif Brodski), w: Pisarz na emigracji..., op. cit., s. 86. Josif Brodski w końcu zaczął być postrzegany 
Zmiana ta była możliwa w warunkach kolejnego cywilizacyjnego przełomu, rozpadu skostniałych po II wojnie światowej porządków - określenie „bez nacji” nie weryfikowało stopnia przywiązania do opuszczonej ojczyzny, lecz wskazywało na zmianę osądu stopnia, w jakim jej brak mógł determinować dyskurs wygnańca.

Z tak obranej perspektywy oglądu przemian współczesnej kultury głos Miłosza mógł być postrzegany nie tylko jako głos emigracyjnego polskiego poety czy poety amerykańskiego, lecz twórcy oferującego rozpoznania i diagnozy o uniwersalnym wymiarze. Karwowska przekonywała: „amerykańskość Miłosza polegała na jego umiejętności wtopienia się w najważniejsze dyskursy krytyczne anglojęzycznego świata - $\mathrm{w}$ tym zmieniające się podejście do wygnania i krytyczną nad nim refleksję"18.

Tym samym kolejne, podlegające ciągłemu dookreślaniu, odsłony autokreacyjnych działań Miłosza mogły inspirować zarówno powstające w różnych krajach akty artystycznego eksplorowania toposu poety-wygnańca, jak i wciąż żywotne $\mathrm{w}$ rozmaitych częściach globu tradycyjne, włączane $\mathrm{w}$ naukowy dyskurs, analizy związków między statusem emigranta a kształtem jego twórczości. Nade wszystko jednak wpływały na związane $\mathrm{z}$ rozkwitem postkolonialnego dyskursu akty przekraczania stereotypowych realizacji tematu.

Jeśli określanie siebie i swojej pozycji w świecie na sposób autonomiczny stanowi świadomie i wciąż od nowa podejmowany trud, to hart ducha jest $\mathrm{w}$ takiej sytuacji warunkiem koniecznym. Miłosz pisał we wspomnieniu o Brodskim:

„Pozwalałem sobie na wszystko prócz skargi" - to powiedzenie Brodskiego powinno być przedmiotem rozmyślań wszystkich młodych, zrozpaczonych i myślących o samobójstwie [...] wygnany z Rosji - postanowił zachowywać się tak, jakby nic się nie zmieniło, nagrodę Nobla równał z dotychczasowymi zmiennymi kolejami losu. Takie postępowanie zalecali starożytni mędrcy, ale niewielu ludzi umie tak postępować w praktyce ${ }^{19}$.

Dystans do siebie i do innych służy zakreślanie granic własnej autonomii. Tak postrzegała specyfikę autoprezentacji emigrantów na styku sfer publicznej i prywatnej, m.in. Irena Grudzińska-Gross, tworząc portret podwójny Miłosza i Brodskiego $^{20}$. Pisząc o ciemnych stronach osobowości twórców - na przykład o egoizmie

jeszcze inaczej, jak pisze badaczka: „jakkolwiek sam wyczulony był na los poety-wygnańca, o czym świadczyć może choćby jego wystąpienie na konferencji poświęconej pisarstwu na wygnaniu w Wiedniu w 1987 roku, to anglojęzyczni krytycy w tym okresie niechętnie zaliczali go do tej grupy. „Poetry Review” w 1986 roku zaproponował stworzenie nowej kategorii, której członkowie nazwani zostali »szczęśliwymi podróżnikami«" (ibidem, s. 87).

18 Ibidem, s. 93-94.

${ }_{19}$ Cz. Miłosz, Życie na wyspach. Kraków 1998, s. 288.

${ }^{20}$ Zob. I. Grudzińska-Gross, Miłosz i Brodski. Pole magnetyczne. Kraków 2007. 
Miłosza czy arogancji Brodskiego - uznawała je także za cechy w pewien sposób dodatnie, bo wspomagające walkę o zachowanie indywidualizmu. Może jednak wyrazistość nieskrywanych przed oczami publiczności wad, jak i przypisywana im (tak jak Oskarowi Miłoszowi) pycha służyć miała po części uwiarygodnieniu autokreacyjnych zabiegów, nade wszystko jednak dopełnieniu i uwypukleniu tego, co nadrzędne w konstruowanych na użytek zbiorowy wizerunkach „buntowników”, nieustannie walczących o zachowanie "hierarchiczności" rozpadających się porządków. Tylko grzesząc pychą można próbować zawracać bieg dziejów.

Wydaje się bowiem, iż w przypadku Miłosza i Brodskiego najważniejsze było łączące ich przekonanie o niezbywalnej wadze działań podejmowanych na przekór cywilizacyjnej erozji, a zmierzających ku ocalaniu wartości oraz wizja tworzenia jako konieczności artystycznego ingerowania we współczesność. Pisarstwo nie tylko jako rodzaj "prywatnego obowiązku”, czy nawet przemożnego wewnętrznego nakazu - stan rozpoznawany także w artystycznych wizjach Oskara Miłosza - ale misja kontynuowania dzieła poetyckiego objaśniania świata i zanurzonego w nim ludzkiego bytu. Miłosz wspominał:

Josif Brodski posunął się nawet tak daleko, że zaprzeczył, jakobyśmy pisali dla naszych potomnych. Według niego piszemy, żeby spodobać się cieniom poetów, którzy nas poprzedzali. Gdyby przemyśleć to zdanie, wynikałyby stąd praktyczne rady dla dumnych awangardzistów, przekonanych, że robią coś, czego nigdy nie znano ${ }^{21}$.

To właśnie misja podtrzymywania wielowiekowej tradycji genialnego, twórczego reagowania na kondycję świata wyznaczała zakres podejmowanych wysiłków reinterpretowania stanu współczesnej kultury. Łączyła się też z faktem, iż wszelkiego typu nauczanie miało charakter jednoznacznych rozpoznań i apodyktycznych nakazów.

Oskar Miłosz, analizując dzieje poezji „po Goethem i Lamartinie”, stwierdzał bez cienia wątpliwości:

poezja pod wpływem czarujących niemieckich romantyków drugiego rzędu jak również pod wpływem Edgara Poe, Baudelaire'a i Mallarmego uległa jakby zubożeniu i zwężeniu, co skierowało ją $\mathrm{w}$ dziedzinę podświadomości ku poszukiwaniom ciekawym zapewne, nieraz nawet godnym podziwu, ale naznaczonym zainteresowaniami natury estetycznej, prawie wyłącznie indywidualnej22.

Potrzeba zatem - zdaniem poety - twórcy genialnego, bowiem przepaść między poezją a rodziną ludzką nie zostanie zasypana, póki nie pojawi się nowoczesny Homer, Szekspir czy Dante: poeta, który wyrzeknie się małego, "ciasnego" ja, by przeniknąć tajemnice wspólnoty. Obowiązkiem artysty jest do takiego ideału

${ }^{21}$ Cz. Miłosz, Spiżarnia literacka, op. cit., s. 114.

22 O.V. de L. Miłosz, Kilka słów o poezji, w: Cz. Miłosz, Prywatne obowiązki. Olsztyn 1990, s. 32. 
dążyć, choćby za cenę wyrzeczenia się poklasku współczesnych. Brodski również zwykł poświęcać uwagę jedynie nielicznym twórcom, których uznawał za niezaprzeczalnie wybitnych. Byli to na przykład Dante, Kawafis, Auden, Mandelsztam, Cwietajewa, Achmatowa, o których pisał m.in. w zbiorze esejów Mniej niż ktoś, budując własną, ale przeznaczoną dla powszechnego zaakceptowania hierarchię. Brodski przekonywał też, bez wahań:

Bycie zwolennikiem absurdu dla siebie, w swojej własnej sztuce itd. jest całkiem w porządku, ale jeśli ktoś w sąsiednim mieszkaniu, kto nie jest artystą, dostaje ciężko po głowie właśnie w wyniku absurdalności tego stulecia, to nie można forsować swego artystycznego stanowiska. Nałożenie się na siebie stylistycznego i egzystencjalnego może wprawić artystę $\mathrm{w}$ ekstazę. I wobec tryumfującego absurdu może on mieć najwyższą pociechę z nazwania samego siebie realistą ${ }^{23}$.

Sprzeciw wobec postawy bezradnej, biernej akceptacji absurdu istnienia i wynikające z niego projekty ocalania wartości miały być może źródło w konieczności nieustannego odnajdywania i ocalania siebie w niemożliwej do ostatecznego oswojenia przestrzeni cywilizacji przeżartej rozpadem. Obu Miłoszów i Brodskiego łączyły bowiem spotkania na „ziemi jałowej”, które - podobnie jak u Eliota nie kończyły się jej opisaniem, lecz próbą aktywnego przeciwdziałania grozie: poszukiwaniem nadziei, kreowaniem wizji ocalenia. Autor Myśli o T. S. Eliocie odsłaniał podobieństwo lirycznych krajobrazów Londynu z Ziemi jałowej i Paryża z Symphonies Oskara Miłosza, wskazując na ich pokrewieństwo jako dzieł „poetów nienasycenia” ${ }^{24}$. Wielokrotnie budził też jego zadumę pewien fakt: „T. S. Eliot, mistrz kilku pokoleń poetów w Anglii i Ameryce, przy końcu życia zaznał odpływu sławy. Nikt o ile mi wiadomo nie uczcił go wierszem po śmierci, z wyjątkiem poety rosyjskiego, nad czym warto się zamyśleć" 25 .

Przezwyciężenie gorzkiej świadomości bytowania na porażonej absurdem istnienia ziemi jałowej dokonać się może tylko dzięki uznaniu, iż istnieje sfera nie poddających się rozchwianiu wartości oraz podjęciu misji obrony ich hierarchicznego trwania. Pod koniec lat osiemdziesiątych Miłosz w jednym z wykładów (zamieszczonym później w Życiu na wyspach) powiedział: „Doznałem przed wojną wpływu Oskara Miłosza i ten nauczył mnie wyniosłego sprzeciwu wobec dekadencji”26. Podobną „wyniosłość sprzeciwu” wobec wszechobecnego rozpadu dostrzegał w biografii i twórczości Brodskiego:

człowiek, który i swoim dziełem, i swoim życiem cały czas przypominał, że wbrew te$\mathrm{mu}$, co się dzisiaj tak często głosi i pisze, istnieje hierarchia. Tej hierarchii nie da się

\footnotetext{
${ }^{23}$ J. Brodski, Rozmowa z Czesławem Miłoszem, w: Historie ludzkie, op. cit., s. 161.

${ }^{24}$ Cz. Miłosz, Prywatne obowiazki, op. cit., s. 125.

${ }_{25}$ Cz. Miłosz, Historie ludzkie, op. cit., s. 62.

${ }^{26}$ Cz. Miłosz, Życie na wyspach, s. 126.
} 
wyprowadzić sylogizmami i ustalić przy pomocy dyskursu. Raczej żyjąc i pisząc utwierdzamy ją co dzień na nowo. Ma ona coś wspólnego z elementarnym podziałem na piękno i brzydotę, prawdę i fałsz [...] hierarchia oznacza szacunek dla tego, co wysokie, i raczej lekceważenie niż pogardę dla tego, co niskie ${ }^{27}$.

„Hierarchiczność" jako akt trudnej wiary w istnienie choćby resztek Porządku i drobin Sensu może zostać uznana za wskazanie i przy dokonywaniu jednostkowych wyborów, i przy tworzeniu dydaktycznych przesłań do zbiorowości. Pamięć o źródłach natchnienia i poczucie wspólnoty z tymi, których uważa się za współtowarzyszy trudnej drogi niezmiennie skłaniały Miłosza do składania kolejnych deklaracji wierności podjętemu niegdyś zobowiązaniu obrony poezji przed desakralizacją - skutkującą nieuchronnie jej marginalizowaniem.

We wspomnianej rozmowie-wywiadzie, którą Brodski przeprowadził, już nie z mentorem, lecz z przyjacielem-Noblistą, autor Drugiej przestrzeni po raz kolejny nawiązał do dzieła Oskara Miłosza, choć już inaczej niż w obszernych, pełnych namaszczenia rozważaniach z Ziemi Ulro, bo wręcz z kolokwialna swobodą. Nadal jednak najważniejszym w dziele krewniaka było otwarcie na możliwą w przyszłości odnowę Ziemi, powtarzał też z przekonaniem, iż „teoria względności otwiera wrota do nowej ery, ery harmonii między nauką, religią i sztuką". Świat newtonowski, zasadniczo wrogi wyobraźni, sztuce i religii musiał zatem utracić swą jednoznaczność, bowiem dla współczesnej fizyki, tak jak niegdyś dla Oskara Miłosza „wszystko jest jednością ruchu, materii, czasu i przestrzeni” 28 . W tej rozmowie dochodzi do uzgodnienia i zbliżenia stanowisk artystycznych, krytycznych, a nawet czytelniczych Miłosza i Brodskiego, zostaje w niej wskazany, przez obu twórców bez wahania „następca” - poeta, tłumacz, emigrant, „genialny chłopak, Staszek" (Miłosz tak skomentował jego dokonania "gdy przeczytałem tłumaczenia Barańczaka, które są fantastyczne, nagle poczułem... Dickinson"29).

Na koniec warto wspomnieć o swoistym zwieńczeniu „prywatnego obowiąz$\mathrm{ku}^{\prime \prime}$ podtrzymywania pamięci o wzorcach wtopionych $\mathrm{w}$ projekt konstruowania własnej tożsamości. Poemat Czeladnik z tomu Druga przestrzeń zadziwia Eliotowskim - choć tylko na pozór - prowokacyjnie anachronicznym kształtem. Podwojonym, bo istniejącym i w lirycznych wersach, i prozatorskich przypisach tekstowym bytem, powtarzającym i scalającym wcześniejsze opowieści w niekwestionowany hołd. Liryczna biografia mistrza po raz kolejny okazuje się w istocie autobiografią „"czeladnika”, zapisem dróg jego duchowego rozwoju, przypomnieniem ważnych zdarzeń i spotkań:

27 Ibidem, s. 278.

28 J. Brodski, Rozmowa z Czestawem Miłoszem, w: Historie ludzkie, op. cit., s. 158.

29 Ibidem, s. 166. Odpowiedź Brodskiego brzmi: „Tak, Staszek, ten chłopak to geniusz, prawda?” I dalej: „To, czego dokonuje w tłumaczeniu, jest zdecydowanie wybitne”. 
Myślę o Wenecji powracającej jak muzyczny motyw,

Od pierwszej mojej tam wizyty przed wojną,

[...]

Po ostatnią, kiedy pogrzebawszy Josifa Brodskiego,

Ucztowaliśmy w palazzo Mocenigo, akurat tym samym,

W którym mieszkał był Lord Byron.

[...]

I to tu Oskar Miłosz, samotny wędrowiec,

Musiał spotkać w 1909 swój wyrok ${ }^{30}$ :

Portret płynnie zmienia się $\mathrm{w}$ autoportret, pożegnanie mistrza jest pożegnaniem świata. W zakończeniu Czeladnika pada raz jeszcze, dobitnie i jednoznacznie wyrażone credo życiowe Miłosza: „Zachowując tonację i styl mojej epoki, / Działać wbrew niej w poezji mojego języka, / to znaczy nie pozwolić, żeby w tym języku, zagubił się zmysł / hierarchii" 31 .

A jednak w poemacie odnaleźć można przeczucie znikomości wszelkich ludzkich wysiłków, zwątpienie, nie tyle w sens podejmowanych przez całe życie działań, co w ich celowość i trwałość efektów:

Wenecja odpływa jak wielki okręt śmierci,

Z rojącym się na jego pokładzie tłumem zmienionym w mary.

Pożegnałem ją na San Michale przy grobach Josifa i Ezry Pounda,

Gotową na przyjęcie ludzi nienarodzonych,

Dla których będziemy jedynie enigmatyczną legendąi2.

Niezrozumiała dla potomnych nierealna opowieść o twórcy i jego dziele - taka być może okaże się w przyszłości pamięć o Poecie. Zaleski przekonywał:

nadpisujący się na tekście biografii Mickiewicza tekst biografii Miłosza jest tekstem zadanym nam do lektury przez samego autora Roku myśliwego (to on, jak można wnosić stymuluje ów "ukryty nurt duchowej autobiografii”), ale Arcywzór biografii poety także zadany przez model kultury, w jakim przyszło mu funkcjonować33.

Tekst ten - czego dowodzą niezliczone opracowania krytyczne powstałe po śmierci Miłosza - umożliwia interpretacje wielorakie. Może być czytany wbrew intencjom autora, dekonstruowany lub unieważniany z najrozmaitszych pozycji badawczych lub ideologicznych. Niezaprzeczalne pozostaje istnienie tego tekstu, który pozostanie wyrazistym punktem odniesienia do biografii każdego z następ-

\footnotetext{
${ }^{30}$ Cz. Miłosz, Druga przestrzeń. Kraków 2002, s. 96.

31 Ibidem, s. 111.

32 Ibidem, s. 98.

${ }^{33}$ M. Zaleski, Arcywzór biografii poety, op. cit., s. 412.
} 
ców, który poważy się sięgnąć po godność narodowego wieszcza. Pozostaje jednak wątpliwość, czy w dzisiejszym modelu kultury jest jeszcze możliwe powtórzenie tego gestu.

\section{Literatura}

Cz. Miłosz, Ziemia Ulro. PIW, Warszawa 1982.

Cz. Miłosz, Prywatne obowiązki. Wyd. Pojezierze, Olsztyn 1990.

Cz. Miłosz, Piesek przydrożny. Wyd. Znak, Kraków 1997.

Cz. Miłosz, Życie na wyspach. Wyd. Znak, Kraków 1998.

Cz. Miłosz, Rodzinna Europa. Wydawnictwo Literackie, Kraków 2001.

Cz. Miłosz, Druga przestrzeń. Wyd. Znak, Kraków 2002.

Cz. Miłosz, Spiżarnia literacka. Wydawnictwo Literackie, Kraków 2004.

Cz. Miłosz, Historie ludzkie. "Zeszyty Literackie” 2007, nr 5.

A. Franaszek, Czesław Miłosz. Biografia. Wyd. Znak, Kraków 2011.

H. Gosk, A. S. Kowalczyk (red.), Pisarz na emigracji. Mitologie, style, strategie przetrwania. Dom Wydawniczy Elipsa, Warszawa 2005.

I. Grudzińska-Gros, Miłosz i Brodski. Pole magnetyczne. Wydawnictwo Literackie, Kraków 2007.

J. Iwaszkiewicz, Dzienniki 1956-1963. Czytelnik, Warszawa 2010.

J. Kwiatkowski (red.), Poznawanie Miłosza. Studia i szkice o twórczości poety. Wydawnictwo Literackie, Kraków 1985.

A. Stankowska, Głos Miłosza w sprawie o "niezrozumialstwo" jako ponowiony wybór tradycji. "Pamiętnik Literacki", CII, 2011, z. 2. 